\title{
First Serodiagnosis of Brucella ovis Among Rams With Epididymo- orchitis in Mosul City, Iraq.
}

\author{
O. K. AL-Hankawei , M. I. Al-Farwachi and O. M. Al-Iraqi \\ University of Mosul, College of Veterinary Medicine, Department of Internal and \\ Preventive Medicine, Mosul, Iraq.
}

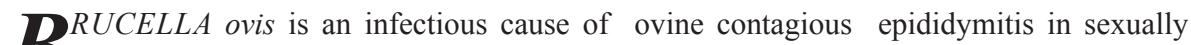
$D$ mature rams, resulting in epididymo-orchitis leading to major economic losses to the sheep industry worldwide.For serodetection of anti Brucella ovis antibodies among sexually mature rams with epididymo-orchitis by using commercial indirect enzyme-linked immunosorbent assays (I-ELISA; IDEXX B. ovis Ab Test kit; Idexx Montpellier, France). During the period from September 2017 to the September 2018, a 200 sera were collected from 42 commercial flocks in Mosul city, Iraq. Scrotal palpation of rams may suggest the presence of this infection in a given flock. The results of the study revealed that, the seropositive animals for $B$. ovis infection was $(12 \backslash 250) 4.8 \%$. The clinical alterations were observed by palpation in the seropositive rams, mainly on epididymes (66.7\%)and testicles (33.3\%), and (83.3\%) alterations were unilateral, and 2/12 (16.7\%) bilateral. This is the first study of serodiagnosis of ovine contagious epididymitis in Mosul city, Iraq. The study provided important information for authorities to planning the control and eradication program.
\end{abstract}

Keywords: Brucella ovis, Ram, indirect ELISA, Epididymo-orchitis, Serodiagnosis.

\section{Introduction}

Ovine contagious epididymitis is a chronic and economically important infectious disease in sheep and goats worldwide [1,2]. Brucella ovis is the main causative agent of disease [2,3]. Unilateral or bilateral of the epididymitis and orchitis are the main signs in the rams leading to reproductive disorders and infertility, and more rarely, abortions in ewes and increased perinatal mortality rates $[2,4]$. transmittinged of disease between animals occurs frequently through the passive venereal route, but ram-to-ram transmission is also common. [5,6] Diagnosis of Contagious epididymo-orchitis can be made using clinical methods, bacteriological and serological tests. Clinical diagnosis lacks sensitivity because not all rams infected with $B$. ovis show palpable genital lesions [7]. Serological tests are preferred for routine diagnosis. Currently, the most widely used tests are Agar Gel Immunodiffusion (AGID), complement fixation test (CFT) and indirect ELISA [3].Several types of I-ELISAs have been designed for detection of antibodies against $B$. ovis antigens with various results [811]. According to literature data, most I-ELISAs appear more sensitive and less prone to problems than the CFT and the AGID [3,12]. Therefore , this study aimed to serodiagnosis of Brucella ovis using commercial I-ELISA ( I-ELISA; IDEXX $B$. ovis Ab Test kit) among rams with epididymoorchitis in Mosul city, Iraq.

\section{Material and Methods}

\section{Sample collection}

For a period of one year (September 2017 to the September 2018). A 250 fresh blood samples were collected from a local breed sexually mature rams with epididymo-orchitis at 42 commercial flocks in the Mosul city (is a major city, located some $400 \mathrm{~km}$ north of Baghdad, Iraq). Blood samples were collected from each ram by jugular venipuncture for sociological analysis and the clinical status of the animals was recorded.

\section{Clinical examination}

A total of 250 local breed rams were evaluated by palpation of scrotal contents to detect testes and epididymis lesions, any differences in size, consistency, shape or swellings in external genitalia were considered abnormal and were registered [2]. 


\section{Serological examination}

Blood samples were centrifuged for ten minutes at $1500 \mathrm{rPM}$ to obtain the serum and then stored in $-20{ }^{\circ} \mathrm{C}$ until use. For detection of anti B. ovis antibodies in the sera, a diagnostic commercial indirect ELISA (I-ELISA; IDEXX Brucella ovis $\mathrm{Ab}$ Test kit; Idexx Montpellier, France).The test was performed following the procedures described by the manufacturer.

\section{Results}

Twelve rams (4.8\%) presented scrotal palpable lesions (epididymo-orchitis) in the Mosul city by using indirect ELISA, IDEXX Brucella ovis $\mathrm{Ab}$ Test kit. In this study, the percentage of negative samples were higher than the positive samples (Table 1). The clinical alterations were observed by palpation in the seropositive rams, mainly on epididymes $8 / 12(66.7 \%)$ and testicles $4 \backslash 12(33.3 \%)$, and $10 / 12(83.3 \%)$ alterations were unilateral, and 2/12 (16.7\%) bilateral.

\section{Discussion}

Brucella ovis is a major infectious cause of ovine contagious epididymitis in sexually mature rams, resulting in economic losses for the sheep industry worldwide $[2,3,6]$. The result of our study was revealed in that $4.8 \%$ of examined rams have antibodies against $B$. ovis., this result represents the first serodiagnosis of ovine contagious epididymitis in Mosul city, Iraq.

Ovine brucellosis caused by Brucella melitensis, and B. abortus was reported in the small and large ruminants in many previous works in the different parts of the Iraq [13-16].

B. ovis infection was confirmed in different countries such as New Zealand [17], Romania [18], Croatia[19.20], Serbia [21], Brazil [22], Argentina [23], India [12,24], France [25] and Turkey [10], while some countries report never having recorded it as in Italy [26], Iran [27], and Canada [28].

TABLE 1. Percentages of the anti Br. ovis antibodies in local breed rams with epididymo-orchitis in the Mosul city

The number of examined animals

Number of positive animals

( \%)

$12(4.8)$
Number of negative animals
In this study, the percentage of negative samples were higher than the positive samples, which can be attributed to either to trauma or to the presence of many species of bacteria causing epididymo-orchitis in ram $[2,4]$.

The most frequently reported bacterial isolates include Actinobacillus seminis, A. actinomycetemcomitans, Histophilus ovis, Haemophilus spp., Corynebacterium pseudotuberculosis ovis, B. melitensis and Chlamydophila abortus [2,4,29].

B.ovis infection was diagnosed in this study using commercially available Indirect ELISA kits [31]. A definitive diagnosis of $B$. ovis infection requires laboratory tests, including serology, bacteriology, and PCR [23,31]. I-ELISA has been shown to be the most sensitive and specific test. As a diagnostic serological method, the ELISA has important advantages over other serological tests commonly used for the diagnosis of ovine brucellosis, such as providing readily measurable results and being easy to perform and standardize $[12,32,33]$.

Egypt. J. Vet. Sci. Vol. 50, No.1 (2019)
Acknowledgment:

This study was supported by the College of Veterinary Medicine, University of Mosul, Mosul, Iraq.

Conflict of interest:

Authors state no conflict of interest.

\section{$\underline{\text { References }}$}

1. Bulgin, M.S. Epididymitis in rams and lambs. Vet. Clin. North. Am. Food Anim. Pract., 6, 683-690 (1990).

2. Peterd, C., Kennethw, W.H , Stanley, H.D. and Walter, G. Veterinary Medicine. A text Book on Disease of Cattle, Sheep, Pigs and Horse $11^{\text {th }}$ ed., Saunders Elsevier, Edinburgh, 1774 p. ( 2017)

3. OIE -World Organization for Animal Health "Chapter 2.7.8. Ovine epididymitis (Brucella ovis)," in Manual of Diagnostic Tests and Vaccines for Terrestrial Animals. Paris: OIE. Available at: http://www.oie.int/fileadmin/Home/eng/Health_ standards/tahm/2.07.08_OVINE_EPID.pdf, (2017). 
4. Aiello, S.E., Moses, M.A. The Merck Veterinary Manual. $11^{\text {th }}$ ed. Kenilworth, NJ: Merck and Co, Brucella ovis, pp. 1339, 1351-2(2005).

5. Cutler, S.J., Whatmore, A.M. and Commander, N.J. Brucellosis - new aspects of an old disease. $J$. of App. Microbiol., 98, 1270 - 1281(2005).

6. Ridler, A.L., Smith, S.L. and West, D.M. Seroconversion and semen shedding in rams experimentally infected with Brucella Ovis. New Zeal Vet J., 62, 47-50 (2014).

7. Poester, F.P., Samartino, L.E. and Santos, R.L. Pathogenesis and pathobiology of brucellosis in livestock. Reviews in Science and Technology Office International des Epizootes., 32 (1), 105115 (2013).

8. Gall, D., Nielsen, K., Vigliocco, A, Smith, P., Perez, B., Rojas, X. and Robles, C. Evaluation of an indirect enzyme-linked immunoassay for presumptive serodiagnosis of Brucella ovis in sheep. Small Rum. Res., 48 (3), 173-179 (2003).

9. Lopez, G., Escobar, G.I., Ayala, S.M. and Lucero, N.E. Detection of antibodies to Brucella ovis in sheep milk using B. ovis and B. canis antigen. Vet. Microbiol., 116 (1-3), 232-238 (2006).

10. Osman, Y.T., Sevil, E.G. and Oktay, K. The Evaluation of Indirect Enzyme-Linked Immunosorbent Assay Using Antigens Prepared from Brucella abortus RB51 and Brucella canis M- Variant Strains for Serologic Diagnosis of Brucella ovis Infection, Kafkas Univ. Vet. Fak. Derg., 22 (1), 63-67(2016).

11. França, S.A., Mol, J.P.S., Costa, E.A., Silva, A.P.C., Xavier, M.N., Tsolis, R.M, Reis, J.K.P., Paixão, T.A. and Santos, R.L. Indirect ELISA for diagnosis of Brucella ovis infection in rams. Arq. Bras. Med. Vet. Zootec., 66 (6) ,1695-1702 (2014).

12. Sadhu D.B., Panchasara, H.H., Chauhan,H.C., Sutariya, D.R., Parmar,V.L. and Prajapati, H.B. Seroprevalence and comparison of different serological tests for brucellosis detection in small ruminants, Vet. World, 8 (5), 561-566(2015).

13. Al-Farwachi, M.I., Al-Iraqi , O.M., Al-Hankawe, O.Kh. and Abdul-Majeed, M.O. Using of competitive ELISA in detection of brucella antibodies in cattle sera in Mosul city, Iraq. Iraqi J. Vet. Sci., 23 (2), 97-103 (2009).

14. Al-Farwachi, M.I., Al- Badrani, B.A. and AlNima, Th. M. Detection of Brucella antigen in the aborted ovine fetal stomach contents using a modified ELISA test. Iraqi J. Vet. Sci., 24 (1) 1-4 (2010).
15. Al-Iraqi, O.M., Al-Hankawe, O.Kh., AbdulMajeed, M.O. and Al-Farwachi M.I. Comparison between competitive ELISAand rose Bengal in the detection of Brucella antibodies in Buffalo sera in Mosul city, Iraq. Bas. J. Vet. Res., 8 (1) 93-95 (2009).

16. Al-Khafaji, W.S. and Al-Farwachi, M.I. Antioxidant status in pregnant ewes vaccinated with Rev 1 against brucellosis Iraqi J. Vet. Sci., 26 (1), 15-19 ( 2012).

17. Ridler, A.L. An overview of Brucella ovis infection in New Zealand. N. Z. Vet. J., 50 (3), 96-(2002).

18. Dobrean, V., Opris, A. and Daraban, S. An epidemiological and surveillance overview of brucellosis in Romania. Vet. Microbiol., 90, $157-$ 163 (2002).

19. Spicić S., Marjanović, S., Zdelar-Tuk, M. and Cvetnić, Z. First evidence of Brucella ovis infection in Republic of Croatia. Dtsch. tierarztl. Wschr., 116 (6), 209-13 (2009).

20. Cvetnicz, Z., Zdelar-Tuk, M., Duvnjak, S., Benic, M., Mihaljevic, Z., Habrun, B., Reil, I., Cvetnic, M. and Silvio Špicic, S. Infectious epididymitis caused by Brucella ovis in Croatian sheep flocks. Turk. J. Vet. Anim. Sci., 41, 679- 685 (2017).

21. Petrović M., Špičić, S., Potkonjak, A., Lako, B., Kostov, M. and Cvetnić, Ž. First evidence of Brucella ovis infection in rams in the Pirot Municipality, Serbia. Vet. Ital., 29,50 (4), 25968(2014)

22. Costa, L.F., Pessoa, M.S., Guimarães, L.B., Silva Faria, A., Morão, R.P., Juliana Pinto, M., Nunes Garcia, L., Almeida, A.C., Gouveia, A.M., Silva, M., Paixão, T. and Santos, R. Serologic and molecular evidence of Brucella ovis infection in ovine and caprine flocks in the State of Minas Gerais, Brazil. BMC Res. Notes, 9, 190-193 (2016).

23. Fiorentino, M.A., Velilla, A., Manes, J., Díaz , A.G., Clausse, M., Paolicchi, F.A. and Estein, S.M. Different strategies for the diagnosis of ovine brucellosis by Brucella ovis in an endemic flock from Argentina . In Vet., 19 (2)11-15 (2017).

24. Saxena, N., Singh, B. and Saxena, H.. Brucellosis in Sheep and Goats and Its Serodiagnosis and Epidemiology. Int. J. Curr. Microbiol. App.Sci.,7 (01), 1848-1877(2018).

Egypt. J. Vet. Sci. Vol. 50, No.1 (2019) 
25. OIE-World Organisation for Animal Health. Manual of Diagnostic Tests and Vaccines for Terrestrial Animals. Paris, France: OIE( 2014).

26. Bertelloni, F., Turchi, B., Cerri, D., Pinzauti, P. and Fratini, F. Leptospira spp. and Brucella ovis seroprevalence in sheep:preliminary results of one year surveillance program J. Hellenic Vet. Med Soc., 68(4), 567-572(2017).

27. Esmaeil, Z., Abdollah, E., Mehran ,Y. Isolation and identification of Brucella organisms in Iran.Iranian J. of Clini. Infect. Dis. , 3(4),185188(2008).

28. Arsenault, J, Girard C, Dubreuil P, Belanger D. Lack of evidence of Brucella ovis infection in rams in Quebec. Can. Vet. J., 45, 312-314 (2004).

29. Moustacas, V.S., Silva, T.M., Costa, L.F., Xavier, M.N., Carvalho, C.A. Jr, Costa, E.A., Paixão, T.A. and Santos, R.L. Species-specific multiplex PCR for the diagnosis of Brucella ovis, Actinobacillus seminis and Histophilus somni infection in rams. BMC Vet. Res., 9, 51 ( 2013).
30. Alvarez J., Veneros, R. and González, O. Validación operacional de un ELISA comercial para Brucella ovis, Chile. Arch. Med. Vet., 39 (3), 275-279 (2007).

31. Xavier M.N., Costa, E.A., Paixão, T.A., Santos, R.L. The genus Brucella and clinical manifestations of brucellosis. Ciência Rural, 39, 2252-2260 (2009).

32. Praud, A., Champion, J.L., Corde, Y., Drapeau, A., Meyer, L. and Garin-Bastuji, B. Assessment of the diagnostic sensitivity and specificity of an indirect ELISA kit for the diagnosis of Brucella ovis infection in rams. BMC Vet. Res., 8, 68 (2012).

33. Vigliocco, A.M., Silva Paulo, P.S., Mestre, J., Briones, G.C., Draghi, G. and Tossi, M. Development and validation of an indirect enzyme immunoassay for detection of ovine antibody to Brucella ovis. Vet. Microbiol., 54, 357-68 (1997).

(Received 06/12/2018; accepted $22 / 01 / 2019$

\section{الكثف المصلي الاولي للبروسيلا الضانية في الكباش المصابة بالتهاب الخصية والبربخ في

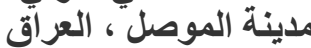

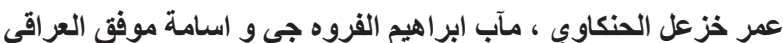

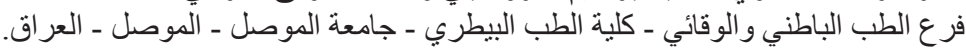

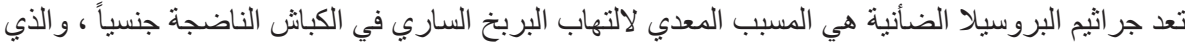

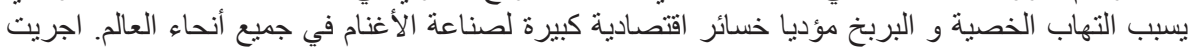

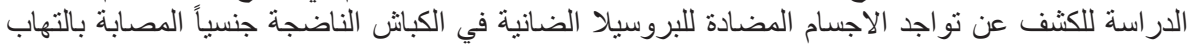

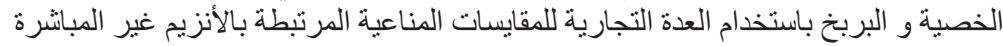

(I-ELISA ‘IDEXX B. ovis Ab Test kit $\leqq$ Idexx Montpellier,France )

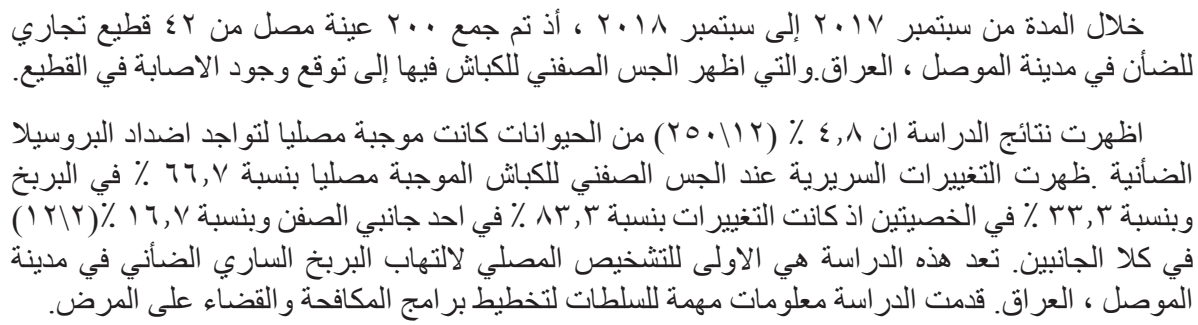

